TOMAsZ DuRAJ

Uniwersytet Łódzki

\title{
POWOŁANIE JAKO PODSTAWA NAWIAZZANIA STOSUNKU PRACY DYREKTORA PRZEDSIĘBIORSTWA PAŃSTWOWEGO
}

\section{ZARYS SYTUACJI PRAWNEJ DYREKTORA PRZEDSIĘBIORSTWA PAŃSTWOWEGO}

Dyrektor przedsiębiorstwa państwowego jest najważniejszym organem zarządzająco-wykonawczym przedsiębiorstwa państwowego' ${ }^{1}$. Będąc głównym reprezentantem jego interesów, powinien dążyć do zapewnienia efektywnego oraz skutecznego funkcjonowania przedsiębiorstwa w obrocie prawnym w długiej perspektywie czasowej. Sytuacje prawną dyrektora przedsiębiorstwa państwowego reguluje ustawa $\mathrm{z}$ dnia $\mathrm{z}$ dnia 25 września $1981 \mathrm{r}$. o przedsiębiorstwach państwowych ${ }^{2}$. Zgodnie z art. 30 cytowanego aktu, dyrektor wykonuje swoje zadania jako piastun organu osoby prawnej, działając obok innych organów przedsiębiorstwa państwowego, którymi są ogólne zebranie pracowników (delegatów) oraz rada pracownicza.

Zasadniczą rolę dla pozycji dyrektora przedsiębiorstwa państwowego odgrywa art. 32 ustawy o pp., według którego jest on uprawniony

${ }^{1}$ Por. szerzej T. Liszcz, Dyrektor przedsiębiorstwa państwowego - jego status prawny, «PiZS» $1982 \mathrm{nr}$ 4; TeJŻE, Stosunek pracy dyrektora przedsiębiorstwa państwowego w PRL, Lublin 1986.

2 Tekst jedn. Dz. U. z 2002 r. Nr 112, poz. 981 ze zm. Dalej ustawa o pp. 
do zarządzania przedsiębiorstwem i reprezentowania go na zewnątrz. Działając zgodnie z przepisami prawa, dyrektor podejmuje decyzje samodzielnie i ponosi za nie odpowiedzialność. Dyrektor przedsiębiorstwa państwowego nie jest jednak jedynym organem zarządzającym i reprezentującym przedsiębiorstwo w obrocie prawnym. Ustawa z dnia 25 września 1981 roku o samorządzie załogi przedsiębiorstwa państwowego $^{3}$ przyznaje bowiem organom samorządowym szereg istotnych kompetencji o charakterze stanowiącym, pozwalających na ich uczestnictwo w procesie zarządzania przedsiębiorstwem państwowym (art. 10 i 24 cytowanej ustawy).

$\mathrm{Na}$ gruncie prawa przedsiębiorstw państwowych obowiązuje podstawowa zasada tzw. domniemania kompetencji decyzyjnych dyrektora przedsiębiorstwa ${ }^{4}$. Oznacza ona, iż dyrektor może podejmować wiążące rozstrzygnięcia we wszystkich sprawach dotyczących przedsiębiorstwa państwowego, które nie zostały w sposób wyraźny zastrzeżone konkretnym przepisem prawa do właściwości stanowiących organów samorządu załogi czy też organu założycielskiego. W tym właśnie zakresie dyrektor, zgodnie z brzmieniem art. 32 ust. 2 ustawy o pp., podejmuje decyzje samodzielnie ponosząc za nie odpowiedzialność. W sytuacji zaistnienia wattpliwości, co do tego czy podmiotem właściwym do rozstrzygnięcia danej sprawy jest organ samorządu załogi, czy też dyrektor przedsiębiorstwa państwowego, przyjmuje się domniemanie kompetencji dyrektora, albowiem jego uprawnienia w zakresie zarządzania przedsiębiorstwem - w przeciwieństwie do kompetencji organów samorządowych - nie zostały określone wyczerpująco, lecz opierają się na generalnej formule, wynikającej z art. 32 ustawy o pp. ${ }^{5}$.

3 Dz. U. Nr 24, poz. 123 ze. zm. Dalej ustawa o szpp.

4 Por.np.A.KIDYBa, Dyrektorjako organ przedsiębiorstwa państwowego, Warszawa 1993, s. 158-160; A. WALASZEK-PyzıoŁ, Organy przedsiębiorstwa państwowego a zasada jednoosobowego kierownictwa, «Krakowskie Studia Prawnicze»1985, s. 62; G. BIEnIEK, Przedsiębiorstwa państwowe - przepisy $i$ komentarz, Warszawa 1997, s. 112-113.

5 Por. np. G. BIEnIEK, Przedsiębiorstwa państwowe, cit., s. 112; Z. KuBot, Odpowiedzialność dyrektora przedsiębiorstwa państwowego, Wrocław 1995, s. 38; 
W literaturze przedmiotu przyjmuje się, iż sposób wyznaczania kompetencji dyrektora pozwala uznać, że w przedsiębiorstwach państwowych nadal znajduje zastosowanie zmodyfikowana zasada jednoosobowego kierownictwa ${ }^{6}$. O utrzymaniu tej zasady świadczą liczne przepisy przyznające dyrektorowi przedsiębiorstwa samodzielną i względnie niezależną pozycję zarówno wobec organów samorządu załogi, jak i organu założycielskiego. Jej gwarancją w stosunku do ogólnego zebrania i rady pracowniczej są przysługujące dyrektorowi przedsiębiorstwa państwowego kompetencje w zakresie wstrzymania wykonania niezgodnych z przepisami prawa uchwał organów samorządu załogi (art. 41 ustawy o szpp.) oraz zaskarżenia uchwał rady pracowniczej, które istotnie naruszają interes ogólnospołeczny (art. 44 ust. 2 ustawy o szpp.). Ponadto samodzielna pozycja dyrektora przedsiębiorstwa państwowego została również zaakcentowana w przepisach regulujących tryb rozstrzygania sporów między nim a radą pracowniczą, które w ostatecznym rozrachunku mogą trafić na drogę sądową. Z kolei gwarancją niezależności dyrektora przedsiębiorstwa państwowego wobec organu założycielskiego jest przyjęta w art. 58 ust. 2 ustawy o pp. zasada ograniczająca prawo władczego wkraczania tego organu w sprawy przedsiębiorstwa jedynie do sytuacji wyraźnie przewidzianych przepisami rangi ustawowej. Zgodnie zaś z art. 63 ust. 1 cytowanej ustawy, dyrektorowi przyznano prawo wniesienia sprzeciwu w stosunku do decyzji podjętych wobec przedsiębiorstwa przez organ założycielski, który ostatecznie może być rozstrzygany w postępowaniu sądowym.

Wyrazem zasady jednoosobowego kierownictwa jest zagwarantowanie dyrektorowi przedsiębiorstwa państwowego szerokich uprawnień do samodzielnego wydawania decyzji, zwłaszcza w zakresie

B. ZIEMIANIN, Aktualne problemy współdziałania dyrektora z organami samorzqdu załogi, [w:] Status prawny dyrektora przedsiębiorstwa państwowego - Materiaty na konferencję naukowa, Poznań 1988, s. 42.

${ }^{6}$ Zob np. Z. КUвот, op. cit., s. 38-39; A. KidYBA, W kwestii obowiqzywania zasady jednoosobowegokierownictwaprzedsiębiorstwempaństwowym, «Organizacja-MetodyTechnika» 1986 nr 6, s. 9-10; W. HofF, Dyrektor a samorząd w przedsiębiorstwie państwowy, «Organizacja-Metody-Technika» 1983 nr 10, s. 6. 
bieżącego zarządzania przedsiębiorstwem, jak również to, iż dyrektorowi podlegają wszyscy pracownicy zatrudnieni w przedsiębiorstwie, wobec których może on działać jednoosobowo ${ }^{7}$. Ponadto, dyrektor przedsiębiorstwa państwowego jest podmiotem wyposażonym przez ustawodawcę $\mathrm{w}$ generalne upoważnienie do reprezentowania tegoż przedsiębiorstwa. W literaturze przedmiotu przyjmuje się, że dyrektor nie ma jednak monopolu cywilnoprawnej reprezentacji przedsiębiorstwa państwowego. Są bowiem sytuacje, w których wyjątkowo uprawnienia do reprezentowania przedsiębiorstwa państwowego przysługują radzie pracowniczej. Dotyczy to głównie sfery stosunków ,administracyjnych", czyli takich, które występują między przedsiębiorstwem państwowym a organem założycielskim ${ }^{8}$.

Podsumowując można stwierdzić, iż dyrektor przedsiębiorstwa państwowego działa w specyficznym układzie zależności, który nie wpływa korzystnie na skuteczność i efektywność funkcjonowania przedsiębiorstw w obrocie gospodarczym. Z jednej bowiem strony, dyrektor musi w procesie zarządzania współpracować z organami samorządu załogi, którym ustawodawca przyznał szereg istotnych kompetencji odnoszących się do spraw o kluczowym znaczeniu dla przedsiębiorstwa. Organy te, uczestnicząc w zarządzaniu przedsiębiorstwem, reprezentują przede wszystkim załogę, co powoduje, iż w praktyce wiele decyzji strategicznych dla przedsiębiorstwa podejmują przez pryzmat interesów pracowniczych, które najczęściej nie są zbieżne $\mathrm{z}$ interesami samego przedsiębiorstwa. Z drugiej zaś strony, mamy do czynienia z sytuacją, w której organ założycielski posiada możliwość skutecznego zablokowania czynności prawnych dokonywanych przez przedsiębiorstwo państwowe, mających za przedmiot jego mienie zaliczone do rzeczowego lub finansowego majątku trwałego

7 A. Kidyba, W kwestii obowiqzywania, cit., s. 10; Z. Кивот, op. cit., s. 39.

${ }^{8}$ Por. np. art. 63 i art. 64 oraz art. 33 ust. 1 i art. 37 ust. 1 ustawy o pp. Por. też m.in.. A. KIDyBa, Dyrektor jako organ, cit., s. 114 i n.; Z. Кuвот, op. cit., s. 39-40; B. KsIĘżopolski, Status prawny dyrektora przedsiębiorstwa państwowego - uwagi wstępne, [w:] Status prawny dyrektora przedsiębiorstwa państwowego $w$ warunkach reformy gospodarczej, red. B. KsIĘżopolski, Wrocław 1983, s. 15-16; B. ZIEMIANIN, op. cit., s. 43. 
(art. 46a ustawy o pp.). Ma on również kompetencję w zakresie wstrzymania wykonania decyzji dyrektora sprzecznych z prawem, zobowiązując go do ich zmiany lub cofnięcia (art. 61 ustawy o pp.). Powyższy układ zależności skutkuje formułą tzw. „,trójkąta bermudzkiego”, która w razie konfliktu może doprowadzić, w skrajnym przypadku, do paraliżu decyzyjnego, co może mieć negatywne konsekwencje dla skutecznego i efektywnego zarządzania przedsiębiorstwem państwowym9

\section{NaWiąZANIE STOSUNKU PRACY NA PODSTAWIE POWOŁANIA Z DYREKTOREM PRZEDSIĘBIORSTWA PAŃSTWOWEGO}

Powołanie jako samodzielna podstawa nawiązania stosunku pracy $\mathrm{z}$ dyrektorem przedsiębiorstwa państwowego po raz pierwszy pojawiło się w dekrecie o przedsiębiorstwach państwowych z dnia 26 października $1950 \mathrm{roku}^{10}$. Artykuł 14 ust. 1 cytowanego aktu stanowil, iż na czele przedsiębiorstwa stoi dyrektor, który samodzielnie kieruje działalnością przedsiębiorstwa i jest za nią odpowiedzialny. Powołanie dyrektora, w trybie art. 14 dekretu z 1950 roku, zgodnie z dominującym stanowiskiem doktryny ${ }^{11}$ oraz orzecznictwa Sądu Najwyższego ${ }^{12}$, uznane zostało za niezależną od umowy o pracę, mianowania, nakazu pra-

9 Por. A. PATUlski, Zatrudnianie i wynagradzanie kadry menedżerskiej średniego $i$ wyższego szczebla, Gdańsk 2001, s. 105-106.

10 Tekst jedn. Dz. U. z 1960 r., Nr 18, poz. 111.

11 Por. m.in. C. StańsKi, O powolywaniu organów przedsiębiorstwa państwowego, «PUG» 6.8/1953, s. 277 i n.; R. CIECHOwICZ, O rejestracji przedsiębiorstw państwowych, «PUG» 6.12/1953, s. 446-447; W. BRONIEWICZ, W kwestii powołania i odwołania dyrektora przedsiębiorstwa państwowego, «NP»11.11/1955, s. 66 i n; P. KŁosIewicz, Instytucja powołania $w$ prawie pracy a powołanie pozorne, «PiP» 21.6/1966, s. 995 i n.; T. BıŃCZYCKA-MAJEwskA, Powołanie na stanowisko dyrektora przedsiębiorstwa państwowego, «PiZS» $1965 \mathrm{nr}$ 11, s. 9; J. JoŃCZYK, Spory ze stosunku pracy, Warszawa 1965, s. 10; Z. SALwA, Systematyka stosunków pracy (ich rodzaje i podmioty), Warszawa 1970, s. 15 i n.

12 Por. np. wyrok SN z dnia 16 lutego 1954 r., I C 2055/53, «NP»10.5-6/1954, s. 179 i n.; wyrok SN z dnia 28 maja 1954 r., II CO 25/54, «PiP» 11.5-6/1956, s. 10721073; uchwała SN z dnia 14-23 grudnia 1959 r., I CO 39/59, «OSN» 1960 nr 4, poz. 91; uchwała SN z 24 stycznia 1959 r., I CO 27/58, OSN 1960, nr 2; wyrok SN z dnia 
cy czy też wyboru, podstawę nawiązania stosunku pracy. Uzasadnienie wyodrębnienia instytucji powołania jako samodzielnej podstawy zatrudnienia dyrektora przedsiębiorstwa państwowego miało charakter wieloaspektowy. Zasadniczym motywem wprowadzenia tej konstrukcji prawnej była chęć zagwarantowania organom państwa, decydującym o obsadzaniu naczelnych stanowisk kierowniczych w gospodarce uspołecznionej, pełnej swobody w zakresie odwoływania dyrektorów przedsiębiorstw $^{13}$, co nie było możliwe w przypadku umowy o pracę czy też nominacji ${ }^{14}$. To z kolei dawało państwu daleko idącą kontrolę w zakresie kierowania gospodarką socjalistyczną ${ }^{15}$. Ponadto, według L. Florka, obsadzenie stanowiska dyrektora w drodze powołania przez jednostkę nadrzędną usytuowaną poza zakładem pracy zapewniało mu większy autorytet wśród załogi oraz niezależność od struktur organizacyjnych funkcjonujących w przedsiębiorstwie państwowym, które to elementy są niezbędne dla prawidłowego wykonywania odpowiedzialnych funkcji kierowniczych ${ }^{16}$.

Kwestię charakteru prawnego stosunku, w ramach którego dyrektor świadczy pracę na rzecz przedsiębiorstwa państwowego rozstrzygnął uchwalony dnia 26 czerwca 1974 roku kodeks pracy ${ }^{17}$. Kodeks ten, będąc pierwszym aktem ustawowym podnoszącym na szeroką skalę instytucję powołania do rangi odrębnej podstawy nawiązania stosunku pracy, usankcjonował tym samym definitywnie prezentowane wcześniej przez przedstawicieli nauki prawa pracy i orzecznictwo sądowe

3 września 1968 r., I PR 276/68, «OSPiKA» 1970, nr 3, poz. 60; wyrok SN z dnia 3 lipca 1964 r., II PR 408/64, «OSPiKA» 1965 nr 7-8, poz. 162.

13 Sam fakt utraty zaufania do dyrektora przedsiębiorstwa państwowego był wystarczającym powodem jego natychmiastowego odwołania $\mathrm{z}$ zajmowanego stanowiska. Por. J. Stelina, Zakres podmiotowy stosunków pracy z powołania po nowelizacji kodeksu pracy, «PiZS» 1996 nr 6, s. 43.

14 Por. np. T. Liszcz, Stosunek pracy dyrektora, cit., s. 91.

15 Por. P. KŁosiewicz, op. cit., s. 1006.

${ }^{16}$ L. FloreK, Instytucja powołania przewidziana $w$ ustawie o pracownikach rad narodowych, «Pal»16.2/1971, s. 44.

17 Tekst jedn. Dz.U. z 1998 r. Nr 21, poz. 94 ze. zm. dalej kp. 
stanowisko, wskazujące na powołanie jako jedyne źródło zatrudnienia dyrektora przedsiębiorstwa państwowego.

Ustawodawca, uchwalając w 1981 roku nową regulację prawną dotyczącą funkcjonowania przedsiębiorstw państwowych w obrocie prawnym, zachował dotychczasową konstrukcję, przewidująca, iż dyrektor jest pracownikiem przedsiębiorstwa państwowego, z którym nawiązanie stosunku pracy następuje w drodze odrębnego aktu powołania. Co więcej, z przepisów ustawy o pp. wynika, że akt powołania w rozumieniu art. 68 i n. kodeksu pracy, może być jedynym dopuszczalnym stosunkiem prawnym, w oparciu o który dyrektor ten będzie mógł świadczyć pracę na rzecz przedsiębiorstwa państwowego ${ }^{18}$. Na uwagę zasługuje jednak fakt, iż powyższa teza nie została wprost sformułowana w jednym przepisie cytowanego aktu, lecz należy ją wyprowadzać z kilku artykułów, zawartych w rozdziale ósmym ustawy o pp., poświęconym problematyce organów tego przedsiębiorstwa ${ }^{19}$.

W literaturze przedmiotu przyjmuje się de lege lata niedopuszczalność zastosowania innej niż powołanie formy zatrudnienia w odniesieniu do dyrektora przedsiębiorstwa państwowego. Oczywiście należałoby zastanowić się nad sytuacja, w której strony - wbrew ustawowemu nakazowi zatrudnienia dyrektora przedsiębiorstwa w oparciu o stosunek pracy z powołania - wykorzystają wobec niego inną podstawę zatrudnienia. W takim przypadku - moim zdaniem - będą istniały uzasadnione przesłanki do tego, aby zastosować do zawartej między stronami czynności prawnej sankcję bezwzględnej nieważności, z uwagi na

${ }^{18}$ Do odosobnionych należy stanowisko, jakie w tej kwestii zajął T. ZIELIŃSKI, Zarys wykładu prawa pracy², II, Katowice 1984, s. 39-40, 42 i 149 który uznał, że w przypadku, gdy dyrektora przedsiębiorstwa państwowego ustanawia rada pracownicza, podstawą nawiązania $\mathrm{z}$ nim stosunku pracy jest wybór w rozumieniu art. 73 kp. Taki pogląd stanowczo skrytykowała T. Liszcz, Charakter prawny aktu powołania na stanowisko dyrektora przedsiębiorstwa państwowego, «PiP» 41.8/1986, s. 94, wskazując iż utożsamianie powołania dyrektora przedsiębiorstwa państwowego przez radę pracowniczą z wyborem jest niezgodne zarówno z przepisami ustawy o pp. dotyczącymi powołania, jak również z przepisami kodeksu pracy o stosunku pracy $\mathrm{z}$ wyboru.

${ }^{19}$ Chodzi tu przede wszystkim o art. 33 i 34 w zw. z art. 38 i 40 ust. 1 ustawy o pp. 
sprzeczność tej czynności z ustawą (art. $58 \S 1$ kc. ${ }^{20}$. W zW. z art. 300 kp.) ${ }^{21}$. Według T. Liszcz ${ }^{22}$, dla zakwestionowania ważności umowy o pracę zawartej z kandydatem na stanowisko dyrektora przedsiębiorstwa państwowego można także wykorzystać cywilistyczną konstrukcję umowy o świadczenie niemożliwe (art. 387 § 1 kc. w zw. z art. 300 kp.).

Zgodnie z art. 33 ust. 1 ustawy o pp. - co do zasady - organem właściwym do powołania dyrektora przedsiębiorstwa państwowego jest rada pracownicza. Także organ założycielski posiada kompetencje w tym zakresie, tyle że w jego przypadku ustawodawca w sposób wyczerpujący określa rodzaje przedsiębiorstw, w których powołuje on dyrektora. Dotyczy to przedsiębiorstw użyteczności publicznej (art. 34 ust. 1 ustawy o pp.), przedsiębiorstw nowo organizowanych oraz tych, w których rada pracownicza w terminie 6 miesięcy nie wykorzystała uprawnień do powołania dyrektora (art. 33 ust. 2 ustawy o pp.), jak również przedsiębiorstw przemysłu obronnego, przedsiębiorstw podległych Ministrowi Finansów, Narodowemu Bankowi Polskiemu i Ministrowi Sprawiedliwości, działających w oparciu o przepisy wykonawcze wydane na podstawie art. 3 ustawy o pp. ${ }^{23}$. Zgodnie z art. 35 ust. 1 ustawy o pp., dyrektora przedsiębiorstwa powołuje się spośród kandydatów wyłonionych w drodze konkursu. Powołanie zaś dyrektora bez przeprowadzenia konkursu jest nieważne ${ }^{24}$.

${ }^{20}$ Ustawa z dnia 23 kwietnia 1964 r. - Kodeks cywilny (Dz.U. Nr 16, poz. 93 ze $\mathrm{zm}$.)

${ }^{21}$ Por. T. Liszcz, Nieważność czynności prawnych w umownych stosunkach pracy, Warszawa 1977, s. 182 i n., zwłaszcza s. 197-198.

22 T. Liszcz, Stosunek pracy dyrektora, cit., s. 68.

${ }^{23}$ Organ założycielski posiada również kompetencje w zakresie powoływania dyrektorów przedsiębiorstw publicznych, do których nie mają zastosowania przepisy ustawy o pp. (art. 4 cytowanej ustawy). Por. szerzej m. in. G. BIENIEK, Przedsiębiorstwa państwowe, cit., s. 113 i n.

24 Szczegółowe zasady realizacji konkursów na stanowisko dyrektora przedsiębiorstwa państwowego określa rozporządzenie RM z dnia 21 grudnia 1994 r. w sprawie organizacji i trybu przeprowadzania konkursu na stanowisko dyrektora przedsiębiorstwa państwowego (Dz.U. Nr 138, poz. 729). Na temat konkursów 
Biorąc pod uwagę przepisy ustawy o pp. oraz art. $68 \S 1 \mathrm{kp}$. należy stwierdzić, iż powołanie dyrektora przedsiębiorstwa państwowego wywołuje podwójny skutek prawny. Po pierwsze, akt powołania powoduje powierzenie danej osobie stanowiska kierowniczego, nadając jej - z mocy ustawy o pp. - status organu przedsiębiorstwa i wyposażając ją w określone prawem kompetencje w sferze zarządzania i reprezentacji. Po drugie zaś, skutkiem tego aktu jest nawiązanie stosunku pracy, do którego w sprawach nieuregulowanych odrębnie ustawą o pp. będą miały zastosowanie przepisy prawa pracy, a w szczególności kodeks pracy. Powyższe skutki następują jednocześnie, przy czym ich trwanie może być zróżnicowane w czasie, bowiem stosunek pracy powstały w tym trybie może trwać dłużej niż piastowane stanowisko dyrektora, na które dana osoba została powołana.

Stosunek pracy dyrektora przedsiębiorstwa państwowego nawiązuje się $\mathrm{w}$ terminie określonym $\mathrm{w}$ akcie powołania, a jeżeli termin ten nie został ustalony, wówczas stosunek zatrudnienia powstaje w dniu doręczenia powołania (art. $68^{2} \S 1 \mathrm{kp}$.). Pomimo iż powołanie dyrektora przedsiębiorstwa państwowego jest jednostronnym aktem uprawnionego organu, to jednak zasadniczą przesłanką powstania na jego podstawie zobowiązaniowego stosunku pracy jest uprzednia zgoda kandydata do pełnienia omawianej funkcji (art. $11 \mathrm{kp}$.) ${ }^{25}$. Zgodnie $\mathrm{z}$ art. 36 ustawy o pp., dyrektor przedsiębiorstwa powoływany jest na okres 5 lat lub na czas nieokreślony.

Ponieważ ustawodawca nie rozstrzygnął w sposób jednoznaczny charakteru prawnego aktu powołania na stanowisko dyrektora przedsiębiorstwa, ani w ustawie o pp., ani w przepisach kodeksu pracy, do dziś w literaturze przedmiotu utrzymują się różne poglądy na temat jego kwalifikacji prawnej ${ }^{26}$. Część przedstawicieli doktryny - nawią-

organizowanych na najwyższe stanowiska kierownicze por. szerzej T. DuRAJ, Pojęcie i klasyfikacja konkursów na stanowiska kierownicze «PiZS» 2001 nr 12, s. 10 i n.; TENŻE, Konkurs na stanowiska kierownicze - wybrane problemy prawne, «Humanizacja Pracy» 2002 nr 4, s. 63 i n.

25 Por. np. L. Florek, T. Zieliński, Prawo pracy, Warszawa 1999, s. 69.

${ }^{26}$ Powyższy spór ma znaczenie nie tylko doktrynalne, bowiem od określenia charakteru prawnego aktu powołania zależy to, według jakich przepisów będzie 
zując do stanowiska, jakie dominowało na gruncie dekretu z 1950 roku - uważa, że akt powołania ma charakter aktu administracyjnego, niezależnie od tego, jaki organ powołuje dyrektora przedsiębiorstwa państwowego $^{27}$. O ile jednak powyższa koncepcja miała swoje uzasadnienie w latach 50., kiedy to dyrektor przedsiębiorstwa był uznawany za organ administracji gospodarczej, a jedynym podmiotem uprawnionym do jego powoływania był organ administracji państwowej, o tyle na gruncie obowiązującego stanu prawnego pogląd ten przestaje być aktualny ${ }^{28}$.

W literaturze przedmiotu można się również spotkać ze stanowiskiem, w myśl którego powołanie należy traktować jako jednostronny akt prawa pracy będący ,aktem polityki kadrowej”, czy też „aktem powierzenia określonego stanowiska"29. Zasadniczą słabością takiej kwalifikacji prawnej aktu powołania jest to, iż nie uwzględnia ona tego, że powołanie dyrektora przedsiębiorstwa państwowego jest również źródłem ustanowienia organu osoby prawnej, a szereg istotnych elementów składających się na instytucję powołania, takich jak podmioty uprawnione do nawiązania stosunku pracy z dyrektorem, tryb tego po-

oceniana wadliwość tego aktu i płynące z niej skutki. Tak m. in. H. LewANDOwSKI, Zakres podmiotowy i przedmiotowy kodeksu pracy. Uwagi 'de lege ferenda', «RPEiS» 50.4/1988, s. 33; T. Liszcz, Charakter prawny aktu powolania, cit., s. 89.

27 Por. np. G. BIENIEK, Niektóre zagadnienia dotyczqce statusu prawnego dyrektora przedsiębiorstwa państwowego, «PiZS» $1982 \mathrm{nr}$ 4, s. $30 \mathrm{i}$ n.; Taki sam pogląd wyraził także SN w uzasadnieniu postanowienia z dnia 25 kwietnia 1983 r. (IV PRN 1/83, «OSPiKA» 1983, nr 12, poz. 268). Por. także m. in. Z. SAlwa, Prawo pracy i ubezpieczeń społecznych, Warszawa 1996, s. 133; T. ZIELIŃsKI, op. cit., s. 38.

${ }_{28}$ Tak H. Lewandowski, [w:] Przedsiębiorstwo państwowe $i$ samorzq̨ jego załogi. Komentarz, red. A. RemBielíśsi, Warszawa-Łódź 1987, s. 225. Przeciwko uznaniu powołania za akt administracyjny opowiedzieli się także m. in. Z. KuBot, W. SANETRA, Odwolanie dyrektora przedsiębiorstwa państwowego, «PiZS» $1983 \mathrm{nr}$ 9, s. 27; A. Patulski, W. Hoff, Dyrektor przedsiębiorstwa państwowego, [w:] Prawo przedsiębiorstw państwowych, red. S. PIĄTEK, Warszawa 1986, s. 87.

${ }_{29}$ Tak m.in. L. BAR, W. SzUBERT, Refleksje nad ustawami o przedsiębiorstwach państwowych $i$ o samorzadzie załogi, «PiP» 38.5/1983, s. 20-21; Kodeks pracy. Komentarz, red. J. JończyK, Warszawa 1977, s. 257. Por. też A. Patulski, W. Hoff, op. cit., s. 88. 
wołania oraz zakres uprawnień i obowiązków dyrektora przedsiębiorstwa, została uregulowana poza prawem pracy, w przepisach ustawy o pp. i innych aktach prawnych dotyczących funkcjonowania tychże przedsiębiorstw ${ }^{30}$.

Trzecia grupa poglądów przyjmuje dualistyczną koncepcję aktu powołania dyrektora przedsiębiorstwa państwowego, uznająca go za instytucję o charakterze międzygałęziowym. Według niej, jeżeli powołania dyrektora dokonuje organ założycielski, wówczas mamy do czynienia $\mathrm{z}$ aktem administracyjnym, z kolei gdy czyni to rada pracownicza, będąca organem samorządu załogi, akt powołania jest czynnością prawną organu kolegialnego (uchwała) ${ }^{31}$. Osobiście jednak uważam, iż de lege lata najbardziej właściwy jest pogląd, w myśl którego instytucja powołania dyrektora przedsiębiorstwa państwowego ma jednolity charakter prawny niezależnie od tego czy organem dokonującym powołania jest organ założycielski, czy też rada pracownicza. Według mnie, powołanie należy traktować jako akt o podwójnej kwalifikacji prawnej (jako decyzję gospodarczą i czynność prawa pracy), który powinien być oceniany przez pryzmat prawa gospodarczego oraz prawa pracy $^{32}$. Z przedstawioną tu koncepcją zbieżne jest stanowisko wyrażone w uzasadnieniu wyroku z dnia 21 października 1983 roku, w którym Sąd Najwyższy charakteryzując stosunki łączące przedsiębiorstwo państwowe z organem założycielskim stwierdził, iż zawierają one w sobie zarówno elementy administracyjne, jak również elementy cywilne, co nadaje tym stosunkom prawnym swoisty charakter stosunków gospodarczo - prawnych, które trudno zakwalifikować do stosunków administracyjno - prawnych. Stosunki te regulowane są-

30 Tak samo m.in. T. Liszcz, Charakter prawny aktu powołania, cit., s. 88; A. NowAK, Odwołanie ze stanowisk $w$ jednostkach samorzqdu terytorialnego obsadzanych na podstawie aktu powołania, «Z Problematyki Prawa Pracy i Polityki Socjalnej, Prace Naukowe UŚ». 9/1992, s. 56-57.

31 Tak np. T. Liszcz, Charakter prawny aktu powołania, cit., s. 90 i n.; J. WiszNIEWsKI, Przedsiębiorstwo państwowe, Warszawa 1988, s. 208; A. KIDYBA, Dyrektor jako organ, cit., s. 32-33.

32 Por. szerzej Z. Kuвот, W. SAnetra, Powołanie dyrektora przedsiębiorstwa państwowego, «PiP» 38.5/1983, s. 34-36. 
zdaniem sądu - wyłącznie przez ustawę o pp. i wydane na jej podstawie przepisy wykonawcze ${ }^{33}$.

Akt powołania dyrektora przedsiębiorstwa państwowego musi być dokonany w formie pisemnej, a w swej treści winien zwierać te wszystkie elementy, których ustawodawca wymaga, zgodnie z art. 29 kp., od stron umowy o pracę $^{34}$. Oznacza to, że akt powołania powinien precyzować strony stosunku pracy nawiązanego na jego podstawie, rodzaj powołania (terminowe czy na czas nieokreślony) oraz warunki pracy i płacy dyrektora przedsiębiorstwa państwowego, a w szczególności: rodzaj pracy; miejsce jej wykonywania; wynagrodzenie odpowiadające rodzajowi pracy, ze wskazaniem jego składników; wymiar czasu pracy oraz termin rozpoczęcia pracy.

Na gruncie obowiązującego stanu prawnego - zgodnie z art. 40 ust. 1 ustawy o pp. - czynności prawne w zakresie stosunku pracy dyrektora przedsiębiorstwa wykonuje organ uprawniony do jego powołania. W uzasadnieniu uchwały z dnia 5 lipca 1991 roku $^{35}$ Sąd Najwyższy stwierdził, iż myślą przewodnią tego przepisu było wprowadzenie przez ustawodawcę regulacji zmierzającej do tego, aby dyrektor nie decydował samodzielnie o swoich płacach i innych roszczeniach majątkowych wobec przedsiębiorstwa w czasie sprawowania swej funkcji. Słuszny wdaje się pogląd zgłaszany w literaturze przedmiotu, iż w cytowanym wyżej art. 40 ust. 1 chodzi o organ uprawniony w danej chwili do powołania dyrektora, a nie ten który go faktycznie powo$ł a ł^{36}$. Według tej interpretacji, pomimo iż w przedsiębiorstwach nowo organizowanych i tych, w których rada pracownicza nie ustanowiła dyrektora $\mathrm{w}$ okresie sześciu miesięcy, podmiotem powołującym go był

33 III PRN I/83, «OSNCP» 1984 nr 6, poz. 95.

34 Wynika to z art. $29 \S 5$ kp., w myśl którego przypisy cytowanego artykułu stosuje się odpowiednio do stosunków pracy nawiązanych na innej podstawie niż umowa o pracę, a więc także do aktu powołania dyrektora przedsiębiorstwa państwowego.

35 I PZP 25/91, «OSNCP» 1992 nr 2, poz. 31.

36 Tak A. Patulski, op. cit., s. 111. Organ faktycznie powołujący dyrektora kształtuje jego warunki pracy i płacy jedynie w fazie nawiązania $\mathrm{z}$ nim stosunku pracy, co sugeruje art. 40 ust. 2 ustawy o pp. Tak też G. BIENIEK, Przedsiębiorstwa państwowe, cit., s. 140. 
organ założycielski, to jednak dalsze kompetencje w zakresie czynności prawnych ze stosunku pracy dyrektora realizować będzie rada, jako „organ uprawniony do powołania dyrektora"37. Pojęcie tych czynności nie zostało przez ustawodawcę doprecyzowane w art. 40 ustawy o pp. Zgodnie z zapatrywaniami doktryny należy przyjąć szerokie rozumienie tego terminu, obejmujące nie tylko czynności prawne sensu stricto dotyczące powstania, realizacji i ustalania stosunku pracy dyrektora przedsiębiorstwa, ale także czynności faktyczne, w szczególności odnoszące się do ustalenia wysokości wynagrodzenia za pracę dyrektora oraz wewnętrznej jego struktury ${ }^{38}$.

\section{ROZWIAZZANIE STOSUNKU PRACY OPARTEGO NA AKCIE POWOŁANIA Z DYREKTOREM PRZEDSIĘBIORSTWA PAŃSTWOWEGO}

W szczególny i nietypowy sposób polski ustawodawca uregulował problematykę rozwiązania z dyrektorem przedsiębiorstwa państwowego stosunku pracy powstałego na podstawie powołania. $\mathrm{O}$ ile bowiem na gruncie obowiązującego prawa nie budzi zastrzeżeń zasada usuwalności osób ze stanowisk obsadzanych w ramach instytucji powołania, oznaczająca nie tylko łatwość dokonywania zmian na tych stanowiskach, lecz również całkowitą swobodę pozbawiania zatrudnienia pracowników, którzy podjęli pracę na podstawie powołania, w każdym czasie i bez konieczności wskazywania jakichkolwiek przyczyn, o tyle w stosunku do dyrektora przedsiębiorstwa państwowego powyższa reguła ulega ograniczeniu, z uwagi na szczególny tryb odwołania tej kategorii pracowników, jaki został przewidziany w ustawie o pp. ${ }^{39}$.

37 Tak G. BIEnIEK, Przedsiębiorstwa państwowe, cit., s. 140.

38 Por. G. Bieniek, tamże. Por. też Z. Kubot, op. cit., s. 91-92. Przy ustalaniu struktury oraz wysokości wynagrodzenia dyrektora przedsiębiorstwa państwowego mają zastosowanie ograniczenia wynikające $\mathrm{z}$ ustawy $\mathrm{z}$ dnia 3 marca $2000 \mathrm{r}$. o wynagradzaniu osób kierujących niektórymi podmiotami prawnymi (Dz.U. Nr 26, poz. 306 ze zm.).

39 Według Z. KuвотA, op. cit., s. 186 ukształtowanie uprawnień do odwołania dyrektora przedsiębiorstwa państwowego jest swoiste, czy wręcz nietypowe, 
Gdy chodzi o kompetencje do odwołania dyrektora przedsiębiorstwa państwowego, obowiązuje generalna zasada, iż uprawnienia w tym zakresie przysługują organowi, który go powołał (art. $70 § 1 \mathrm{kp}$.). Ustawa o pp. przewiduje jednak pewne odstępstwa od powyższej reguły, co przede wszystkim dotyczy przedsiębiorstw nowo organizowanych oraz tych, w których organ założycielski powołał dyrektora, jeżeli rada pracownicza nie wykorzystała w terminie 6 miesięcy przysługujących jej w tym zakresie uprawnień (art. 33 ust. 2 ustawy o pp. ${ }^{40}$. Specyfika omawianego trybu wiąże się z tym, iż ustawodawca przewidział możliwość wzajemnego wpływania organu założycielskiego i rady pracowniczej na decyzje w zakresie odwołania dyrektora przedsiębiorstwa państwowego. Nie sposób nie zauważyć tego, że ustawa stawia organ założycielski w uprzywilejowanej pozycji, przyznając mu stanowczy wpływ na odwołanie dyrektora przez radę pracowniczą. Wynika to $\mathrm{z}$ art. 37 ustawy o pp., zgodnie z którym rada ta może odwołać dyrektora przedsiębiorstwa jedynie za zgodą organu założycielskiego. Jej brak skutkuje zaś nieważnością uchwały podjętej bez dopełnienia powyższego wymogu. Ponadto, ustawa o pp. przyznała organowi założycielskiemu dosyć szerokie kompetencje do podejmowania samodzielnych decyzji dotyczących odwołania dyrektora przedsiębiorstwa, w stosunku do których radzie pracowniczej nie przysługuje sprzeciw w trybie art. 63 cytowanego $\mathrm{aktu}^{41}$. Pewnym wzmocnieniem uprawnień rady $\mathrm{w}$ omawianym zakresie jest unormowanie zawarte w art. 45 ustawy o pp., które ma zastosowanie do przypadków, gdy podmiotem wła-

w porównaniu z pozbawieniem stanowiska osób zarządzających innymi organizacjami gospodarczymi, zwłaszcza członków zarządu spółek kapitałowych.

${ }^{40} \mathrm{~W}$ obu wskazanych tu przypadkach ustawodawca przyznaje organowi założycielskiemu jedynie prawo powołania dyrektora, natomiast kompetencje w zakresie jego odwołania przysługująjuż radzie pracowniczej. Ponadto, odstępstwem od zasady wyrażonej w art. $70 \S 1 \mathrm{kp}$. jest także regulacja zawarta w art. 37 ust. 4 ustawy o pp., w ramach której organ założycielski odwołuje dyrektora przedsiębiorstwa $\mathrm{w}$ razie nie odwołania go przez radę pracowniczą z przyczyn, o których mowa $\mathrm{w}$ art. 42 ustawy o pp. Por. np. G. BienieK, Przedsiębiorstwa państwowe, cit., s. 125; A. Patulski, op. cit., s. 106.

${ }^{41}$ Dotyczy to decyzji, które organ założycielski może podejmować w związku z zaistnieniem przyczyn wskazanych w art. 37a i 65 ustawy o pp. 
ściwym do usunięcia dyrektora ze stanowiska jest organ założycielski. W takiej sytuacji rada pracownicza może wystąpić do tego organu z wnioskiem o odwołanie dyrektora przedsiębiorstwa, jeżeli swoją działalnością poważnie naruszył on przepisy prawa, bądź gdy swoją nieprawidłową pracą spowodował, że przedsiębiorstwo nie osiagnęło zadowalających wyników gospodarczych. Przesłanki uzasadniające złożenie stosownego wniosku są sformułowane na tyle szeroko i nieprecyzyjnie, iż wiele zachowań dyrektora może podlegać dyspozycji art. 45 ust. 1 ustawy o pp., w tym także i takie, które nie mogą być rozpatrywane w kategoriach działań zawinionych ${ }^{42}$. Organ założycielski zobowiązany jest w ciagu dwóch tygodni uwzględnić złożony wniosek lub przeprowadzić postępowanie wyjaśniające. Jeżeli postępowanie to potwierdzi zarzuty zgłaszane pod adresem dyrektora przedsiębiorstwa, organ założycielski będzie zmuszony odwołać go w terminie siedmiu dni. W przypadku zaś pojawienia się rozbieżności stanowisk w odniesieniu do wyników postępowania wyjaśniającego, rada pracownicza może zgłosić sprzeciw, który podlega rozpatrzeniu w trybie art. 63 cytowanej ustawy. Jeżeli mimo sprzeciwu organ założycielski nie odwoła dyrektora przedsiębiorstwa, wówczas sprawa może zostać przekazana do właściwości sądu, który w terminie czternastu dni wyznacza rozprawę ${ }^{43}$. Warto również zauważyć, że na gruncie ustawy o pp. dyrektor nie ma żadnych kompetencji uprawniających go do zaskarżenia decyzji o jego odwołaniu, nawet w sytuacji, gdyby została ona podjęta w sposób jednoznacznie naruszający prawo. W postanowieniu

${ }^{42}$ Por. H. Lewandowski, [w:] Przedsiębiorstwo państwowe i samorzad, cit., s. $257-$ 258.

43 Rada pracownicza może złożyć sprzeciw od decyzji organu założycielskiego dotyczącej odwołania dyrektora przedsiębiorstwa także w innych przypadkach, pod warunkiem, że przepisy ustawy o pp. expressis verbis nie wyłączają takiej możliwości (np. art. 37 ust. 5). Powyższe rozumowanie wynika z art. 63 w zw. art. 38 ustawy o pp. Według Z. KuвотA, op. cit., s. 200 w sprawach dotyczących odwołania dyrektora przedsiębiorstwa - co do zasady - rolą sądu nie powinno być orzekanie o zasadności odwołania, a tylko o niezgodności z prawem decyzji odwołującej. Od tej reguły moim zdaniem - są jednak wyjątki, które wynikają choćby z art. 45 ust. 1 ustawy o pp. 
z dnia 12 lipca 1985 roku Sąd Najwyższy ${ }^{44}$ wskazuje jednak, iż dyrektor przedsiębiorstwa państwowego może - w procesie między organem założycielskim a radą pracowniczą o ustalenie bezskuteczności jego odwołania - wystapić z interwencją uboczną po stronie organu skarżącego odwołanie ${ }^{45}$. Należy także zauważyć, iż na gruncie obowiązującego stanu prawnego nie ma żadnych przeszkód, aby odwołany dyrektor wystapił do organu, który posiada prawną możliwość zakwestionowania decyzji odwołującej z odpowiednią inicjatywą.

Na uwagę zasługuje fakt, iż możliwość odwołania z zajmowanego stanowiska w takim samym stopniu dotyczy wszystkich dyrektorów przedsiębiorstw państwowych, niezależnie od tego czy zostali oni powołani na okres pięciu lat, czy też na czas nieokreślony. Oznacza to, że terminowe powierzenie danej osobie funkcji dyrektora przedsiębiorstwa nie prowadzi do wzrostu stabilizacji jej zatrudnienia, bowiem żaden przepis ustawy o pp. nie wyłącza możliwości odwołania dyrektora przed upływem okresu, na jaki go powołano. Podobny wniosek wynika zresztą z przepisów kodeksu pracy regulujących odwołanie pracowników zatrudnionych w ramach powołania, które mają także zastosowanie do dyrektora przedsiębiorstwa państwowego (art. 38 ustawy o pp.). Ustawodawca w art. $70 \S 1 \mathrm{kp}$. expressis verbis stwierdził bowiem, iż pracownik zatrudniony na podstawie powołania może być w każdym czasie odwołany ze stanowiska przez organ, który go powołał, co dotyczy również pracownika powołanego na czas określony, na podstawie przepisów szczególnych. Powyższe unormowania prowadzą - moim zdaniem - do wniosku, że ustanowienie wobec dyrektora przedsiębiorstwa instytucji powołania na okres pięciu lat ma tylko takie znaczenie, iż po upływie tego czasu stosunek pracy z dyrektorem wygasa z mocy samego prawa, bez potrzeby podejmowania w tym celu jakiejkolwiek czynności przez którąkolwiek ze stron ${ }^{46}$.

44 IV PPZ 2/85, «OSNCP» 1986 nr 3, poz. 42.

45 Por. też uchwałę SN z dnia 23 marca 1993 r., I PZP 1/93, «OSNCP» 1993 nr 12, poz. 210.

${ }^{46}$ Tak m. in. T. Liszcz, Dyrektor przedsiębiorstwa państwowego, cit., s. 22. 
W nauce prawa powszechnie przyjmuje się, iż akt odwołania dyrektora przedsiębiorstwa państwowego ${ }^{47}$ wywołuje podwójny skutek. Po pierwsze, pozbawia on daną osobę zajmowanego stanowiska oraz związanych z nim kompetencji w zakresie zarządzania i reprezentacji przedsiębiorstwa państwowego, co może nastapić niezwłocznie lub w terminie określonym w decyzji o odwołaniu. Po drugie zaś, akt odwołania prowadzi do ustania stosunku pracy, przy czym w świetle przepisów kodeksu pracy odwołanie dyrektora przedsiębiorstwa może być równoznaczne bądź to z wypowiedzeniem umowy o pracę (art. 70 $\S 2 \mathrm{kp}$.), bądź z rozwiązaniem umowy o pracę bez wypowiedzenia, jeżeli nastapiło z przyczyn określonych w art. 52 lub $53 \mathrm{kp}$. (art. $70 \S 3$ kp.). O ile jednak w sytuacji, gdy odwołanie dyrektora przedsiębiorstwa wiąże się z rozwiązaniem umowy o pracę bez wypowiedzenia, oba wskazane powyżej skutki zachodzą równocześnie, o tyle w przypadku odwołania tożsamego z wypowiedzeniem umowy o pracę najczęściej jest tak, że utrata stanowiska następuje znacznie wcześniej niż ustanie stosunku pracy. Nie budzi wątpliwości to, iż pozbawienie dyrektora przedsiębiorstwa pełnionej funkcji i przysługujących mu z tego tytułu uprawnień musi nastąpić najpóźniej z chwilą zakończenia stosunku pracy ${ }^{48}$.

Aby zharmonizować tryb odwołania dyrektora przedsiębiorstwa uregulowany w ustawie o pp. ze skutkami, jakie wywołuje ono wobec stosunku pracy na gruncie przepisów kodeksu pracy, ustawodawca przyjął w art. 38 ustawy o pp. odpowiednią konstrukcję prawną. Według niej, jeżeli od decyzji odwołującej dyrektora zgłoszono sprzeciw, rozwiązanie stosunku pracy z odwołanym dyrektorem następuje w trybie i na zasadach określonych w art. 70-72 kp., dopiero po cofnięciu sprzeciwu przez organ, który go wniósł albo oddaleniu przez sąd wniosku o uchylenie decyzji o odwołaniu dyrektora.

W przypadku, gdy odwołanie jest równoznaczne z wypowiedzeniem umowy o pracę, co do zasady, bieg okresu wypowiedzenia, liczonego

47 Problem charakteru prawnego aktu odwołania dyrektora przedsiębiorstwa państwowego jest postrzegany w literaturze przedmiotu w analogiczny sposób do tego, jak interpretuje się akt powołania.

${ }^{48}$ Por. szerzej T. Liszcz, Odwołanie ze stanowiska dyrektora, cit., s. 30-32. 
według reguł określonych w art. $36 \mathrm{kp}$, rozpoczyna się po podjęciu decyzji odwołującej dyrektora, $\mathrm{z}$ chwilą gdy doszła do niego w taki sposób, iż mógł on zapoznać się z jej treścią (art. 61 kc. w zW. z art. 300 kp. $)^{49}$, nie wcześniej jednak, niż po wyczerpaniu postępowania odwoławczego uregulowanego w ustawie o przedsiębiorstwach państwowych $^{50}$. Od powyższej zasady ustawodawca przewidział w art. $72 \S 1$ kp. wyjątek podyktowany względami natury ochronnej. Jeżeli bowiem odwołanie dyrektora nastapiło w okresie usprawiedliwionej nieobecności w pracy, bieg wypowiedzenia rozpoczyna się dopiero po upływie tego okresu. W okresie wypowiedzenia dyrektor zachowuje wszystkie dotychczasowe prawa i obowiązki wynikające ze stosunku pracy, w tym także dotyczące kierowania przedsiębiorstwem i jego reprezentowania na zewnątrz, o ile decyzja o odwołaniu nie skutkowała natychmiastowym pozbawieniem go zajmowanego stanowiska. W takim przypadku, mimo iż dyrektor nie świadczy pracy na rzecz przedsiębiorstwa państwowego i tak zachowuje przez cały okres wypowiedzenia prawo do wynagrodzenia w wysokości przysługującej przed jego odwołaniem (art. 70 § 2 zdanie drugie kp.). Nie ma oczywiście żadnych przeszkód, aby w okresie, tym na wniosek lub za zgodą dyrektora, pracodawca zatrudnił go przy innej pracy, odpowiedniej ze względu na jego kwalifikacje zawodowe.

Jeżeli zaś odwołanie dyrektora przedsiębiorstwa państwowego jest równoznaczne z rozwiązaniem stosunku pracy bez wypowiedzenia ${ }^{51}$, pozbawienie stanowiska i ustanie stosunku pracy następują jednocześnie z chwilą, gdy decyzja o odwołaniu doszła do niego w taki sposób, iż mógł on zapoznać się z jej treścią (art. 61 kc. W zW. z art. 300 kp.),

${ }^{49} \mathrm{Na}$ taką interpretację wskazuje art. 70 § 1 k.p., zgodnie z którym odwołanie powinno być dokonane na piśmie, co jednoznacznie sugeruje jego związek z obowiązkiem doręczenia dyrektorowi decyzji o odwołaniu z zajmowanego stanowiska.

50 Por. uchwałę SN z dnia 8 listopada 1988 r.,III PZP 34/88, «OSNCP» 1990 nr 1, poz. 8 i uzasadnienie uchwały SN z dnia 16 maja 1991 r., I PZP 3/91, «OSNCP» 1992 nr 3, poz. 35 .

51 Por. np. wyrok SN z dnia 14 maja 1998 r., I PKN 113/98, «OSN» 1999 nr 9, poz. 307; wyrok SN z dnia 1 października 1998 r., I PKN 360/98, «OSN» 1999 nr 21, poz. 682 . 
przy czym oba skutki - moim zdaniem - mogą nastapić nie wcześniej niż po wyczerpaniu postępowania odwoławczego uregulowanego w ustawie o przedsiębiorstwach państwowych.

W odniesieniu do dyrektora przedsiębiorstwa państwowego, tak samo jak wobec innych pracowników zatrudnionych na podstawie powołania, ustawodawca - na mocy art. $69 \mathrm{kp}$. - istotnie ograniczył ochronę trwałości stosunku pracy. Powszechnie przyjmuje się, iż w przypadku odwołania dyrektora przedsiębiorstwa państwowego nie ma zastosowania uprzednia kontrola zamiaru rozwiązania $\mathrm{z}$ nim stosunku pracy realizowana przez funkcjonujące w danym przedsiębiorstwie związki zawodowe ${ }^{52}$, natomiast kontrola sądowa w zakresie wadliwego rozwiązania stosunku pracy dyrektora została znacząco zawężona. I tak, zarówno w sytuacji, gdy odwołanie jest równoznaczne z wypowiedzeniem umowy o pracę, jak również z rozwiązaniem umowy o pracę bez wypowiedzenia, dyrektorowi przedsiębiorstwa państwowego nie przysługuje ani roszczenie o uznanie odwołania za bezskuteczne, ani roszczenie o przywrócenie do pracy na dotychczasowym stanowisku. W takim przypadku dyrektor ma jedynie prawo do dochodzenia odszkodowania, co wynika z art. 69 kp., który nie wyłączył tego roszczenia wobec pracowników odwołanych w trybie art. 70 § 2 i $3 \mathrm{kp}$. Sąd orzekając o odszkodowaniu na rzecz dyrektora przedsiębiorstwa musi oczywiście ustalić, iż jego odwołanie równoznaczne z rozwiązaniem stosunku pracy dokonane zostało wadliwie, w sposób naruszający przepisy obowiązującego w tym zakresie prawa.

W stosunku do dyrektora przedsiębiorstwa państwowego, podobnie jak w odniesieniu do innych pracowników zatrudnionych na podstawie powołania, istotnemu ograniczeniu ulega również ochrona szczególna, która sprowadza się na gruncie kodeksu pracy do dwóch zasadniczych elementów. Pierwszy z nich dotyczy sytuacji, w której odwołanie dyrektora jest równoznaczne $\mathrm{z}$ wypowiedzeniem umowy o pracę. Tutaj ochrona szczególna polega na zawieszeniu biegu okresu wypowiedzenia w przypadku, gdy odwołanie nastapiło w czasie usprawiedliwionej

52 Por. np. T. Liszcz, Problem ochrony trwałości stosunku pracy na stanowisku dyrektora, «PiZS»1983 nr 12, s. 12; Z. SALWA, Kodeks pracy. Komentarz, Warszawa 1996, s. 106. 
nieobecności dyrektora spowodowanej, np. urlopem czy też chorobą (art. $72 \S 1 \mathrm{kp}$.). Drugi zaś, związany jest z sytuacją, kiedy to adresatem decyzji odwołującej dyrektora przedsiębiorstwa państwowego jest kobieta w okresie ciąży lub pracownik, któremu brakuje nie więcej niż dwa lata do nabycia prawa do emerytury z Funduszu Ubezpieczeń Społecznych (art. 72 § 2 i 3 kp.). Wówczas ustawodawca nałożył na organ odwołujący dyrektora przedsiębiorstwa obowiązek zaproponowania mu na piśmie innej pracy, odpowiedniej ze względu na jego kwalifikacje zawodowe. W przypadku, gdy odwołany dyrektor odrzuci ofertę innej pracy, jego stosunek pracy ulega rozwiązaniu z upływem okresu równego okresowi wypowiedzenia, którego bieg rozpoczyna się od dnia złożenia mu stosownej propozycji.

Pewną rekompensatą mniejszej stabilności zatrudnienia dyrektora przedsiębiorstwa państwowego, w porównaniu z sytuacją pracowników zatrudnionych na podstawie umowy o pracę na czas nieokreślony, było wprowadzenie przez prawodawcę - ustawą z dnia 9 marca 1990 roku ${ }^{53}$ - instytucji odprawy, jaka przysługuje odwołanemu dyrektorowi na zasadach określonych w art. 39 ustawy o pp. Zgodnie z art. 39 ust. 4 ustawy o pp., omawiana tu odprawa powinna być wypłacona w dniu rozwiązania stosunku pracy.

W literaturze przedmiotu przyjmuje się, iż odwołanie dyrektora przedsiębiorstwa państwowego nie jest jedynym sposobem rozwiązania jego stosunku pracy. Wynika to choćby z art. 69 kp., który nakazuje stosować do tego stosunku, w kwestiach nieuregulowanych, przepisy dotyczące umowy o pracę na czas nieokreślony, także w zakresie dopuszczalnych metod zakończenia stosunku pracy. Oznacza to, iż do rozwiązania stosunku pracy z powołania może również dojść zarówno na mocy porozumienia stron, jak i z inicjatywy samego dyrektora, bądź to poprzez wypowiedzenie przez niego stosunku pracy, bądź w drodze rozwiązania niezwłocznego w trybie art. $55 \mathrm{kp}$. Ponadto, o czym była już wcześniej mowa, w przypadku powołania na okres pięciu lat, sto-

${ }^{53}$ Ustawa o zmianie ustawy o przedsiębiorstwach państwowych (Dz.U. Nr 17, poz. 99). 
sunek pracy dyrektora przedsiębiorstwa państwowego rozwiązuje się z mocy samego prawa z upływem okresu, na jaki został zawarty.

Podsumowując należy stwierdzić, iż sytuacja dyrektora przedsiębiorstwa państwowego w zakresie stabilizacji jego zatrudnienia jest znacznie korzystniejsza od tej, jaką posiadają inni pracownicy zatrudnieni na podstawie powołania. Trzeba bowiem pamiętać, że konstrukcja tej podstawy zatrudnienia, uregulowana w przepisach kodeksu pracy, w swoim założeniu przewiduje pozostawienie organowi powołującemu daleko idącej swobody w przedmiocie rozwiązania tego stosunku pracy oraz zasadnicze wyłączenie sądowej kontroli w przypadku odwołania pracownika skutkującego ustaniem stosunku pracy z powołania. Tymczasem na gruncie ustawy o pp. możliwość swobodnego odwołania dyrektora przedsiębiorstwa państwowego została istotnie ograniczona poprzez wprowadzenie kompromisowego mechanizmu, w ramach którego zarówno rada pracownicza, jak i organ założycielski posiadają określone uprawnienia, umożliwiające im wzajemny wpływ na decyzje dotyczące pozbawienia dyrektora zajmowanego stanowiska, które bądź to mogą doprowadzić do całkowitego zablokowania decyzji odwołującej ${ }^{54}$, bądź też mogą skutkować pojawieniem się sporu rozstrzyganego na drodze sądowej ${ }^{55}$. O ile z jednej strony taka sytuacja jest korzystna dla samego dyrektora przedsiębiorstwa z uwagi na niewątpliwe wzmocnienie trwałości jego zatrudnienia, o tyle $\mathrm{z}$ drugiej strony, w sposób istotny przyczynia się do niepotrzebnego zaciemnienia i komplikacji samego mechanizmu odwoływania dyrektora, negatywnie rzutując na jego odpowiedzialność za wyniki przedsiębiorstwa $^{56}$. Bardzo często w praktyce prowadzi to do tego, iż odwołanie dyrektora przedsiębiorstwa staje się przedmiotem konfliktu interesów, przetargów czy też kompromisów pomiędzy radą pracowniczą a organem założycielskim, co niewątpliwie nie sprzyja efek-

54 Taka sytuacja występuje w przypadku braku zgody organu założycielskiego, która jest niezbędna dla odwołania dyrektora przez radę pracowniczą.

55 Dotyczy to sprzeciwu zgłoszonego wobec decyzji odwołującej dyrektora przedsiębiorstwa państwowego.

56 Por. Z. КUвот, op. cit., s. 215-216. 
tywności i skuteczności zarządzania przedsiębiorstwem państwowym w warunkach gospodarki rynkowej. Stąd też, aby przeciwdziałać tym negatywnym zjawiskom pojawiają się w literaturze głosy wskazujące na konieczność odejścia od kompromisowej zasady samorządności przedsiębiorstw państwowych na rzecz przyznania organowi założycielskiemu lub radzie nadzorczej, zdominowanej przez przedstawicieli Skarbu Państwa, wyłącznych kompetencji w zakresie odwoływania dyrektora przedsiębiorstwa, nie podlegających możliwości kwestionowania przez załogę przedsiębiorstwa państwowego, w tym także na drodze sporu sądowego ${ }^{57}$.

Należy również pamiętać o odprawie, która przysługuje odwołanemu dyrektorowi przedsiębiorstwa na zasadach określonych w art. 39 ustawy o pp., przyczyniając się korzystnie do stabilizacji jego sytuacji zatrudnieniowej. Pozytywnie oceniając wykorzystanie tej instytucji wobec dyrektora uważam, iż na uwagę zasługuje również propozycja wprowadzenia dodatkowego ubezpieczenia tej kategorii osób zarządzających od ryzyka utraty pracy ${ }^{58}$. Oba powyżej wskazane instrumenty, w moim przekonaniu, byłyby wystarczającymi elementami stabilizującymi zatrudnienie dyrektora przedsiębiorstwa państwowego.

Appointment as the Basis for Establishing Employment Relationship of a Director of a State Enterprise

\section{Summary}

The subject of this study is a detailed characteristics of the act of appointment as the basis for employment relationship of a director of a state enterprise. The director is the most important managing and executive body of a state enterprise, and the legal status of a director is regulated by the State Enterprises Act of 25 September 1981.

57 Tamże.

58 Taką propozycję zgłaszała m.in. T. Liszcz, [w:] Stosunek pracy dyrektora, cit., s. 266 . 
In relation to a director of a state enterprise there is a special situation, within which there is a legal obligation to utilize the employment relationship by appointment as the basis for employment. It is the only admissible legal relation, on the basis of which a director can work for a state enterprise.

The employee status of a director of a state enterprise is primarily regulated by the labor code regulations regarding appointment (articles 6872 of the labor code), while, according to article 69 of the labor code, to this employment relation - with some exceptions -the regulations regarding employment contracts for an unspecified time are also applicable.

In this article the author analyses the issue of establishing and terminating the employment relation with a director of a state enterprise. Particular attention ought to be paid to the specific situation of a director of a state enterprise with regard to the stabilization of his or her employment. It is significantly more advantageous as compared to the situation of other employees employed by appointment. According to the regulations in force, there are no reservations to the principle of removing persons from the posts filled within the institution of appointment in any time and without the necessity to indicate any causes. However, this principle is limited with relation to a director of a state enterprise, due to the specific procedures of dismissal of this category of employees statutory by the act of state enterprises as well as additional rights to which a dismissed director is entitled, especially the right for a dismissal allowance. 